\title{
Agenda for the 35th General Assembly of the European Association for the Study of Diabetes to be held in Brussels, Belgium, in the Auditorium 2000 of the Brussels Exhibition Centre, Heysel, on Friday, 1 st October 1999 from 17:30-18:30 h.
}

1. Minutes of the 34 th General Assembly, Barcelona, Spain

2. Reports
a) President
b) Honorary Treasurer
J. Nerup
c) Honorary Auditors
R.J. Heine
d) Honorary Secretary
R. Landgraf
J. Skrha
e) Editor-in-Chief, Diabetologia
M. Porta
W. Waldhäusl

\section{Elections}
a) Honorary Treasurer 2000-2003
in place of
R.J. Heine
b) Council Members 2000-2003
in place of
T. Halmos (Hungary)
M. Hod (Israel)
D. Koev (Romania)
I. Valverde (Spain)
4. Postgraduate Education Sub-Committee

A.J.M. Boulton

5. Study Groups

6. The European Foundation for the Study of Diabetes

7. Membership Fees for Associate/Supporting Members
8. Honorary Membership
L. Heding (DK/Zimbabwe)

9. Any other business 